\title{
Contributions of the nurse's clinical practice to Primary Care
}

\author{
Contribuições da prática clínica do enfermeiro para o cuidado na Atenção Primária \\ Las contribuciones de la práctica clínica del enfermero a la asistencia en la Atención Primaria
}

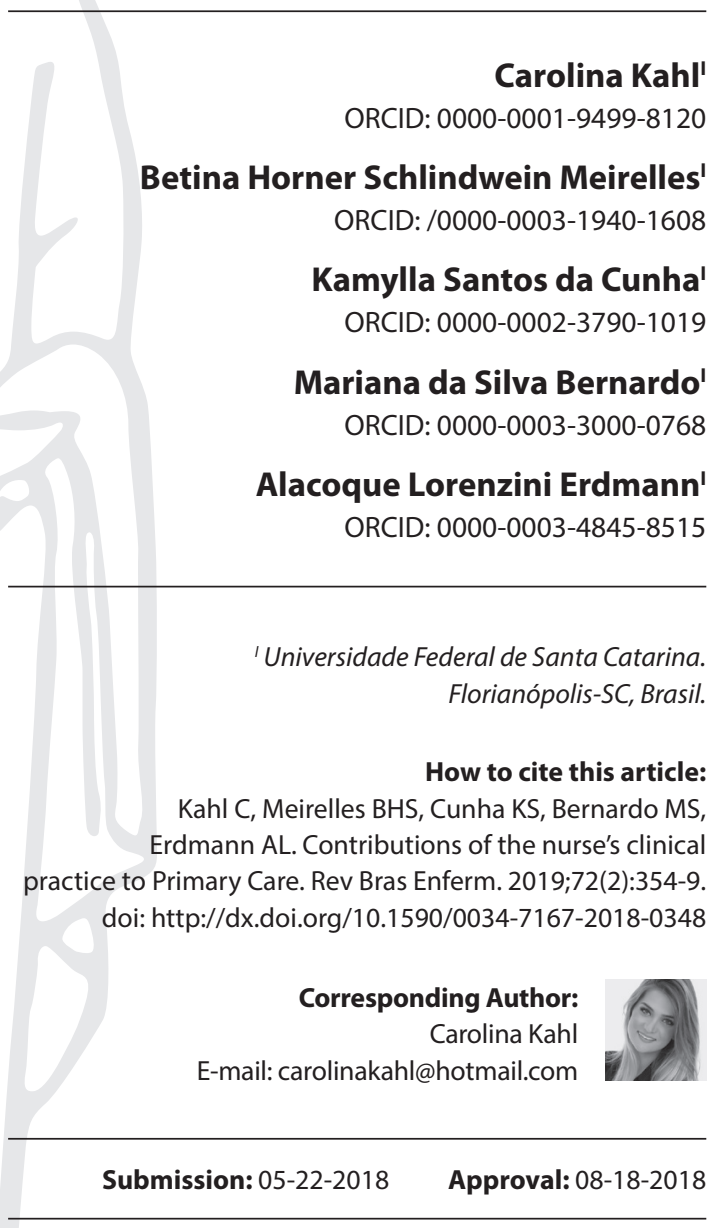

\begin{abstract}
Objective: To understand the repercussions of the nurse's clinical practice on Primary Health Care. Method: Qualitative research with the theoretical and methodological contribution of Grounded Theory. Data collection took place between May and October 2016 in Florianópolis' Primary Care service. The theoretical sample was comprised of 18 nurses divided into two groups. Results: nurses' clinical practice has repercussions on the consolidation of the trust bond between individuals, families and communities, by amplifying the problem-solving efficacy of the Primary Health Care professional's clinical practice. This is due to the implementation of clinical nursing protocols, and also the use of the International Classification for Nursing Practice. Final considerations: Nurses' clinical practice has positive repercussions on the health of Primary Health Care users. Keywords: Nursing; Primary Health Care; Evidence-Based Practice; Nursing Evaluation Research; Standardized Nursing Terminology.
\end{abstract}

\section{RESUMO}

Objetivo: Compreender como a prática clínica do enfermeiro repercute no cuidado aos usuários na Atenção Primária à Saúde. Método: Pesquisa qualitativa com aporte teórico metodológico da Teoria Fundamentada nos Dados. A coleta de dados ocorreu entre maio e outubro de 2016 no serviço de Atenção Primária de Florianópolis. A amostragem teórica compreendeu 18 enfermeiros divididos em dois grupos. Resultados: A prática clínica do enfermeiro repercute na consolidação do vínculo de confiança com os indivíduos, família e comunidade através da ampliação da resolutividade da prática clínica do profissional na Atenção Primária à Saúde pela implementação dos protocolos clínicos de enfermagem e, também, do uso da Classificação Internacional para a Prática de Enfermagem nesse cenário e suas contribuições para uma prática clínica efetiva e de qualidade. Considerações finais: A prática clínica do enfermeiro repercute de maneira positiva no cuidado à saúde dos usuários na Atenção Primária à Saúde.

Descritores: Enfermagem; Atenção Primária à Saúde; Prática Clínica Baseada em Evidências; Avaliação em Enfermagem; Terminologia Padronizada em Enfermagem.

\section{RESUMEN}

Objetivo: Identificar cómo la práctica clínica del enfermero influye en la asistencia a los usuarios de la Atención Primaria a la Salud. Método: Investigación cualitativa, utilizándose como marco teórico-metodológico la Teoría Fundamentada en los Datos. La recolección de datos ocurrió entre mayo y octubre de 2016, en el servicio de Atención Primaria de Florianópolis, Brasil. El muestreo teórico comprendió a 18 enfermeros, siendo que fueron divididos en dos grupos. Resultados: La práctica clínica del enfermero influye en la consolidación del vínculo de confianza con los individuos, la familia y la comunidad por medio de la ampliación de resolutividad de la práctica clínica del profesional en la Atención Primaria a la Salud por la implementación de los protocolos clínicos de enfermería y por el uso de la Clasificación Internacional para la Práctica de Enfermería, en este escenario, y sus contribuciones a una práctica clínica efectiva y de calidad. Consideraciones Finales: La práctica clínica del enfermero influye positivamente en la asistencia a los usuarios de la Atención Primaria a la Salud. Descriptores: Enfermería; Atención Primaria de Salud; Práctica Clínica Basada en la Evidencia; Evaluación en Enfermería; Terminología Normalizada de Enfermería. 


\section{INTRODUCTION}

Nurses' daily clinical practice can be understood as a complex of activities and actions which, supported by evidence-based practice, aim for integral attention to the health of users, family and community ${ }^{(1)}$.

In the context of Primary Health Care (PHC) - which plays a central role in the health system within the Health Care Network $^{(2)}$ - clinical practice focuses on overcoming curative logic, acting towards health promotion and the prevention of diseases and injuries. To this end, nurses' clinical practice employs multiprofessional attitudes in its relationships to the community, answering to the different demands typical of this scenario. In this sense, it is necessary for the relationships that emerge between subjects during the exercise of clinical practice to be dialogical, horizontal, welcoming, and anchored in care co-responsibility ${ }^{(3)}$.

A review study with the purpose of listing and analyzing factors potentiating or hindering the clinical practice of nurses in the Family Health Strategy (FHS) highlighted the expanded clinic as a potentiating factor, due to its capacity for user embracement and the systematization of nursing care. Among hindering factors, the influence of the biomedical model, the poor qualification of nurses for the implementation of the nursing process, and inadequate organizational and infrastructure conditions were highlighted ${ }^{(4)}$.

In the professional field of nursing, evidence-based clinical practice emerges to foster nurses' critical thinking and judgment in the face of the population's health-disease demands, contributing to a more secure and compatible decision-making process ${ }^{(5)}$. Given the particularities of the PHC scenario, and the potentialities and difficulties encountered in the way of professional practice, it is important for the nurse, together with the multiprofessional team, to adopt strategies that circumvent potential hindrances, so that clinical practice positively impacts on integral and quality health care. Thus, we formulated the following research question: in this scenario, how does the clinical practice developed by the $\mathrm{PHC}$ nurse affect user care?

\section{OBJECTIVE}

To understand the repercussions of nurse's clinical practice on Primary Health Care.

\section{METHODS}

\section{Ethical aspects}

The study followed ethical precepts for research involving human beings, according to norms and guidelines by Resolution 466/12 of the National Health Council. The study's project has been approved by the Ethics and Research with Human Beings Committee of the Federal University of Santa Catarina.

After being informed about the purpose of the study and its ethical aspects, participants signed a Free and Informed Consent Term, accepting their participation. In order to preserve their identity and guarantee their anonymity, they were identified in the speech excerpts below by a code represented comprised of the letter $\mathrm{N}$ (Nurse), followed by the interview number (N1, N2, N3 ...), and the letter $G$ (Group), referring to the sample group $(G 1, G 2)$.

\section{Theoretical and methodological background}

As a theoretical and methodological referential, we adopted the Straussian version of the Grounded Theory, which seeks to explain social phenomena from the meanings attributed by people who experience them. Participants answer questions related to the given phenomena, involving its who, what, where, why, how, as well as its consequences( ${ }^{(6)}$.

\section{Type of study}

A qualitative-approach study.

\section{Methodological procedures}

This article originates from a master's thesis entitled Attributing meaning to the clinical practice of the nurse in Primary Health Care (Significando a prática clínica do enfermeiro na Atenção Primária à Saúde), which discusses the phenomenon of integral care in the clinical practice of Primary Health Care nurses. The thesis was based on the Systematization of Nursing Care method, which is supported by three components (or categories).

The first component, "conditions," refers to the conditions and justifications provided by people about why and how certain phenomena occur. The second, "actions-interactions," presents individuals' responses to the problematic situations experienced in a given context. The last component, "consequences," corresponds to the repercussions, real or expected, of the resolution of problematic situations arising from the relationships, actions and interactions established by the people involved in the process or phenomenon studied ${ }^{(6)}$. Given the relevance of the "consequences" component, we decided to deepen its discussion in this article.

\section{Hypothesis}

In the interviews conducted with the first sample group, nurses reported the use of nursing protocols as an aid and basis for their practice, also emphasizing that it helped develop their clinical practice by expanding the scope of their actions in respect to $\mathrm{PHC}$ user demands. These protocols were conceived and developed by the Permanent Commission for Systematization of Nursing Assistance (CSAE), formed by nurses of the Health Care Network together with the PHC technical representation in the municipality. Thus, we hypothesized that the CSAE was of great importance in encouraging the expansion of clinical practice and the autonomy of the nurse in the $\mathrm{PHC}$, given its responsibility for the elaboration of clinical nursing protocols. In this sense, the participation of nurse-members of the CSAE in this research would contribute significantly to the understanding of the phenomenon under study.

\section{Scenario of the study}

The study was developed in Florianópolis' Primary Care network, which has 49 health centers in five health districts. Eleven health centers participated in the study. These were selected for having the highest number of spontaneous demand visits among all health districts. 


\section{Data source}

The participants were 18 nurses divided into two sample groups. The first sample group was comprised of ten nurses, intentionally selected among the ten health centers with the highest number of spontaneous demand consultations, according to data obtained from the Municipal Health Department of the municipality.

The inclusion criteria for the group were: nurses who had integrated the Family Health Strategy for at least six months, and who provided direct assistance to health users in spontaneous demand consultations.

The second sample group consisted of eight nurses who met the following inclusion criterion: participation in the CSAE and in a health center, providing direct assistance to the population.

The exclusion criterion for both groups was to be away from work during data collection. Thus, two nurses who were on leave of absence were excluded from the second sample group.

\section{Data collection and organization}

The data were collected from May to October 2016 through open interviews, with the following guiding question: "Tell me about your clinical practice in caring for users of the Primary Health Care."The interviews were carried out in the health center, in a reserved room of the participants' choice, with an average duration of 30 minutes, audio-recorded and later transcribed in full. To aid in the organization of the data at the time of analysis, NVivo ${ }^{\circledR} 11$ software was employed.

\section{Data analysis}

Comparative data analysis was performed, determining the differences and similarities between the pieces of information and reducing them into concepts with definite attributes and dimensions ${ }^{(6)}$.

The process of analysis had three interdependent stages: I) open codification, in which the concepts were identified and their attributes and dimensions discovered, grouping similar facts and events into topics; II) axial coding, where categories were associated with subcategories, in order to obtain a more complete explanation of the phenomenon; III) integration, the final process of developing the theory, which consisted in linking the previously created categories with a central category.

The study followed the paradigmatic model proposed by Corbin and Strauss, comprised of three components: conditions; actions-interactions; and consequences ${ }^{(6)}$.

The theoretical saturation necessary for concluding the study was ascertained from the repetition of information and the absence of new elements relevant to the research, as well as the consolidation of the categories necessary for understanding the phenomenon. To assist in the analysis process, memoranda and diagrams were also used, as recommended by the aforementioned model ${ }^{(6)}$.

\section{RESULTS}

The findings of the study elucidate the repercussions of nurses' clinical practice on PHC user care. This is especially true for the category "Consolidating the bond of trust with the community through the expansion of nurses' autonomy and resolve," supported by the two subcategories presented below.

\section{Extending the problem-solving efficacy of clinical practice on the basis of nursing protocols}

The nurses emphasized clinical nursing protocols as a tool of professional consultations, providing greater subsidy for the development of the PHC clinical practice, and also bringing possibilities of actions for tracing medical history, diagnosis and choice of the most indicated healthcare conducts.

The protocols were elaborated by a committee of nurses, whose practice ranges from providing direct assistance in the health centers and managing the municipality's PHC network, to participating in the CSAE, which gathers experts in the subjects approached by each protocol, bringing the best possible scientific evidence to task in fulfilling PHC user needs. These protocols have four volumes: I) Hypertension, Diabetes and other factors associated with cardiovascular diseases; II) Sexually transmitted diseases and other communicable diseases of collective health interest (dengue and tuberculosis); III) Women's health in primary care; and IV) Adult Spontaneous Demand Care. Participants reported that the use of such protocols broadened the alternatives and possibilities of nursing diagnoses and interventions in a unified and informed way.

With the implementation of the protocols, nurses began having legal support for prescribing and renewing prescriptions in special cases, in which the patient's clinical situation is stable. According to reports, this increased nurses' autonomy and, consequently, the problem-solving efficacy of their clinical practice, besides providing greater agility during patient consultations.

\begin{abstract}
There was this extension of the nurse's clinical practice ... During visits when the person asks, for instance: "I want to renew my prescription for blood pressure medicine" ... I have [in the protocol] the criteria for what I'm able to prescribe. I can prescribe the medication myself, and also ask for routine exams, besides making an appointment for the person to come back another day. Before, that kind of patient would never receive a consultation by a nurse, see? (N12G2)
\end{abstract}

Some nurses perceive a more comprehensive implementation of the Ministry of Health's guidelines and protocols in the municipality of Florianópolis, in comparison to other municipalities in which they have previous healthcare work experience.

I worked in another municipality where I didn't have that much freedom. I'd fulfill the more programmed, expected demands, but when I came here [Florianópolis] I saw a very different situation ... I began tending to adults and young people who were not part of any programs whatsoever, or even children in non-anticipated situations... The model that the municipalities employ varies from one municipality to another, but I think [the implementation of the protocols] is very important; I think this contributes to the nurse's practice, it shows that we have that capacity [for handling more healthcare situations]. (N2G1)

It should be emphasized that the nursing protocols are available online at the city hall's website. According to the CSAE, this 
is due to possible changes and updates in the protocols, based on their continuous evaluation and the needs identified by practicing nurses.

With the protocols' implementation, the training on their use and on the new clinical assignments became part of nurses' routine. Nurses meet regularly to discuss questions and strategies in the use of the protocols or a given emerging need of daily professional practice.

\section{Adopting the International Classification for Nursing Practice in nurses' PHC clinical practice}

Clinical nursing protocols are linked to the International Classification for Nursing Practice (ICNP), also adopted by the CSAE. The ICNP is a computerized system that aims to create an universal language for nursing practice, by standardizing the records of nursing consultations and making available a controlled vocabulary of specific nursing diagnoses and interventions.

Nurses have broad expectations regarding the contributions of the ICNP to their clinical practice in community health care. Although the ICNP is still being tested in municipal health centers, it has been the subject of many discussions among the network's nurses, who report positive contributions of its systematization of care to clinical practice.

I think it will be positive ... a methodology for the nurse is necessary, because we do a lot of things and then fail to record what we do. We are diagnosing daily and the work is very busy, but it appears as if the nurse has been doing nothing, because there is no record. (N9G1)

The computerized system currently used by Florianópolis' health centers is called InfoSaúde. It adopts the SOAP (Subjective, Objective, Assessment and Plan) as one of its nursing care documentation methodologies, while allowing for different ways of recording nurses' clinical practice. The ICNP is scheduled to be implemented into InfoSaúde as a complementary system, aiming at improving the quality of care through new registration forms, electronic medical records and better communication among nurses.

We have selected the ICNP to help organize the nursing record ... we have a monthly meeting with pilot health centers that help build interventions and improve diagnosis ... we have already built the basis for InfoSaúde, that is, for how the electronic medical record should function. (N11G2)

Based on the periodic assessment on the use of the ICNP conducted by the pilot health centers, it is possible to develop health-education actions geared towards professionals. Many nurses believe that training and workshops allow for betterexecuted clinical management and therapies, since the workshops are opportunities to discuss and plan the best treatment for the diagnoses most commonly presented by patients.

[The use of the ICNP] is very interesting, because it allows us to see which diagnoses occur the most, and even think about permanent education ... With the ICNP you can better-visualize your community, you can see how it is diagnosed. (N12G2)
With the ability for identifying nursing consultations' most frequent diagnoses, one can have an overview of the health center's coverage area and a better understanding of its community, thus establishing and increasing community bonds.

When you have a bond, you get to know the patient, the patient's complaints, family, medicines currently in use, and even whether the patient is adhering to the treatment or not. (N7G1)

In short, actions developed through nursing clinical protocols and the ICNP strengthen the trust bond between nurse and community, with the latter recognizing in the former a member of the health team who knows how to evaluate and provide effective responses to their demands. Such a professional can become a genuine community reference.

\section{DISCUSSION}

The findings of this study mainly regard the repercussions of nursing clinical protocols and the ICNP on the care provided to $\mathrm{PHC}$ users. The use of these protocols in the PHC was evidenced as a tool able to guide, support and extend the autonomy of the nurse over the course of clinical practice.

As corroboration for these results, we highlight that the literature discusses the repercussions of nursing protocols to the care of chronic patients. Protocols contribute with positive values by strengthening therapeutic adherence, stimulating changes in patients' lifestyles, and reinforcing the professional-patient relationship, with consequent improvements in health outcomes ${ }^{(7)}$.

A study of nurses' PHC performance in England's National Health Service discusses protocol-guided clinical practice of nurses in chronic-patient care ${ }^{(8)}$. Clinical nursing protocols, besides helping systematize care and contributing to patient safety by controlling variations in care practice among professionals, strengthen the nurses' work process and its basis on up-to-date clinical evidence ${ }^{(9)}$.

Protocols are an important tool in the systematization of care. However, their use has to be directed towards an approximation between the theoretical and the practical fields of the nursing profession and the different demands of society ${ }^{(10)}$. This is the end-goal of the systematization of care, as an inherent aspect of nursing care which serves to organize and improve the quality of care, unify the language used by nurses in their diagnosis, and promote the autonomy of professionals ${ }^{(11)}$.

The ICNP appears in nurses' discourse as complementary to nursing protocols and the systematization of care. As an instrument, it is able to expose crucial elements of nurses' clinical practice, such as common diagnoses, performed interventions and their results. Besides, it aids in systematizing the collected data, improving the quality of care and possibly leading to positive changes in nursing practice through education, management and research based on the perspective of the individual patient, family and community ${ }^{(11-12)}$.

Although the ICNP has many advantages, its use in clinical practice is still uncommon, at least in the $\mathrm{PHC}$ context. The infrequent use of an unified language for $\mathrm{PHC}$ nurses' records is shown here and in other studies as an important hindrance to 
nurses' clinical practice ${ }^{(13-14)}$. The clear and simple unification of language provided by the ICNP facilitates health education by directing educational care according to diagnostic data.

Also, the implantation of nursing diagnoses through the ICNP favors the distinction of nursing-practice concepts, providing better visibility to the type of care for which the nurse is responsible ${ }^{(15)}$. However, acquiring a nursing diagnosis requires the professional to master theoretical knowledge, practical experience, and critical judgment, combined with precise information on the patients' health-illness status ${ }^{(12,16)}$.

Based on the nursing diagnosis, the nurse is able to elaborate an individualized plan of care, considering the particular health conditions of each individual, the surrounding psychosocial aspects, as well as the patient's potentialities and frailties ${ }^{(17)}$, thus involving the PHC user in the elaboration of the care plan.

In this vein, a study carried out in Canada's PHC service, aimed at examining the experience of patients and their families as part of a case management intervention, emphasized the importance of patient participation in the development of the care plan ${ }^{(18)}$.

With the active involvement of the patients in decision-making and in the elaboration of the care plan, the patients reported feeling that their needs were properly considered and their choices respected. Since this work is a specific responsibility of the nurse, the latter can be considered a reference when it comes to informing, educating, supporting and facilitating the patient's pathway through the health system ${ }^{(18)}$.

The link between nurse and community reflects a commitment to the integrality of care essential to PHC work. The nursing consultation articulates a clinical practice consolidated towards the prevention of diseases, patient recovery and health promotion, as well as the development of health education practices accessible to individuals, family, and community ${ }^{(19-20)}$.

\section{Limitations of this study}

This study was limited to only one scenario of data collection, and so its results cannot be generalized to other scenarios.

\section{Contributions to the field of nursing}

This research may contribute to nurses' knowledge and practice through the adoption of strategies and tools that subsidize it and aid in its development, bringing positive consequences to healthcare and nursing.

\section{FINAL CONSIDERATIONS}

This study's findings indicate that the development of nurses' clinical practice in the context of $\mathrm{PHC}$ has a positive impact on the health care of users. This impact takes place especially by means of two innovative strategies, pertinent to this health scenario and to the studied municipality: clinical protocols and the adoption of the ICNP. Clinical nursing protocols reinforce the use of evidencebased practice beyond the hospital context, reinforcing the role of critical judgment and decision-making in the PHC. The use of the ICNP-which has not been officially implemented in all the municipality's health centers-in electronic medical records already shows positive results by contributing to the strengthening of the nurse's clinical practice and to greater quality in the health care of individuals, families and communities.

\section{REFERENCES}

1. Borges CL, Freitas MC, Guedes MVC, Silva MJ, Leite SFP. Nursing clinical practice in the frail elderly care: reflection study. Rev Enferm UFPE[Internet]. 2016[cited 2018 Apr 12];10(Suppl. 2):914-18. Available from: https://www.researchgate.net/publication/299305005_ nursing_clinical_practice_in_the_frail_elderly_care_reflection_study_pratica_clinica_do_enfermeiro_no_cuidado_ao_idoso_fragilizado_ estudo_de_reflexao_practica_clinica_del_enfermero_en_el_cuidado_al_an

2. Rodrigues LBB, Silva PCS, Peruhype RC, Palha PF, Popolin MP, Crispim JA, et al. [Primary Health Care in the coordination of health care networks: an integrative review]. Ciênc Saúde Coletiva[Internet] 2014[cited 2018 Apr 12];19(2):343-52. Available from: http://www.scielo.br/ pdf/csc/v19n2/1413-8123-csc-19-02-00343.pdf Portuguese.

3. Pinto AGA, Jorge MSB. [Clinical practice in the family health strategy: relationships between team and users in urban territory]. Rev G\&S[Internet]. 2015[cited 2018 Apr 12];6(2):1514-29. Available from: http://periodicos.unb.br/index.php/rgs/article/view/22483/16080 Portuguese.

4. Costa RHS, Couto CRO, Silva RAR. [Clinical practice of nurses in the Family Health Strategy]. Saúde (Santa Maria)[Internet]. 2015 [cited 2018 Apr 12];41(2):9-18. Available from: https://periodicos.ufsm.br/revistasaude/article/download/10841/pdf Portuguese.

5. Camargo FC, Garcia LAA, Santos AS, Iwamoto HH. Evidence-based practice: bibliometric review of national publications in nursing journals. REFACS[Internet]. 2017[cited 2018 Jul 10];5(3-Esp):429-39. Available from: seer.uftm.edu.br/revistaeletronica/index.php/refacs/article/ download/2137/pdf_1

6. Corbin J, Strauss AL. Basics of qualitative research: techniques and procedures for developing Grounded Theory. 4th ed. Los Angeles: SAGE; 2015.

7. Shaw RJ, McDuffle JR, Hendrix CC, Edie A, Lindsey-Davis L, Nagi A, et al. Effects of nurse-managed protocols in the outpatient management of adults with chronic conditions. Ann Intern Med[Internet]. 2014[cited 2018 Apr 19];161(2):113-21. Available from: https://www.ncbi.nlm. nih.gov/pubmed/25210722

8. Toso BRGO, Filippon J, Giovanella L. Nurses' performance on primary care in the National Health Service in England. Rev Bras Enferm [Internet]. 2016[cited 2018 Apr 19];69(1):169-77. Available from: https://www.ncbi.nlm.nih.gov/pubmed/26871232

9. Diniz IA, Cavalcante RB, Otoni A, Mata LRF. Perception of primary healthcare management nurses on the nursing process. Rev Bras 
Enferm[Internet]. 2015[cited 2018 Apr 19];68(2):182-9. Available from: http://dx.doi.org/10.1590/0034-7167.2015680204i

10. Yakuwa MS, Andrade RD, Wernet M, Fonseca LMM, Furtado MCC, Mello DF. Nurses' knowledge in child health primary care primary. Texto Contexto Enferm [Internet]. 2016[cited 2018 Apr 19];25(4):1-8. Available from: http://www.scielo.br/pdf/tce/v25n4/0104-0707tce-25-04-2670015.pdf

11. Silva ES, Castro DS, Romero WG, Garcia TR, Primo CC. Nursing protocol for psychosocial and spiritual alterations of the person with colostomy. Cogitare Enferm[Internet]. 2015[cited Apr 25];20(3):466-73. Available from: https://revistas.ufpr.br/cogitare/article/ view/40664/26187

12. Bittencourt GR, Oliveira FM, Santana RF, Marques D, Rocha ICM, Cavalcanti ACD. [Knowledge and practices of nursing students on nursing classification systems]. Enferm Cent O Min[Internet]. 2016[cited 2018 Apr 25];6(2):2247-57. Available from: http://www.seer.ufsj.edu.br/ index.php/recom/article/view/969/1107 Portuguese.

13. Avelino CCV, Costa LCS, Buchhorn SMM, Nogueira DA, Goyatá SLT. Teaching-learning evaluation on the ICNP ${ }^{\circledR}$ using virtual learning environment. Rev Bras Enferm[Internet]. 2017[cited 2018 Apr 25];70(3):602-9. Available from: http://www.scielo.br/pdf/reben/v70n3/00347167-reben-70-03-0602.pdf

14. Clares JWB, Nóbrega MML, Guedes MVC, Silva LF, Freitas MC. Bank of terms for clinical nursing practice with community elderly. Rev Eletr Enf[Internet]. 2016[cited 2018 Apr 25];18(e1167):1-8. Available from: https://revistas.ufg.br/fen/article/view/37759/21672

15. Coelho MMF, Miranda KCL, Guedes MVC, Monteiro ARM, Silva LF, Leite ACS. [Applicability of ICNP ${ }^{\circledast}$ based on the theory of modeling and role-modeling]. Rev Bras Enferm[Internet]. 2014[cited 2018 Apr 28];67(3):438-42. Available from: http://www.scielo.br/pdf/reben/ v67n3/0034-7167-reben-67-03-0438.pdf Portuguese.

16. Forsberg E, Ziegert K, Hult H, Fors U. Clinical reasoning in nursing, a think-aloud study using virtual patients - a base for an innovative assessment. Nurs Educ Today[Internet]. 2014[cited 2018 May 3];34(4):538-42. Available from: https://www.ncbi.nIm.nih.gov/ pubmed/23938093

17. Parsons LC, Revell MA. Clinical Updates in Pathophysiology and Care Protocols for Nursing Management. Nurs Clin North Am[Internet]. 2015[cited 2018 May 3];50(4):xv-xvi. Available from: https://www.ncbi.nlm.nih.gov/pubmed/26596667

18. Hudon C, Diadiou F, Lambert M, Bouliane D. Case management in primary care for frequent users of health care services with chronic diseases: a qualitative study of patient and family experience. Ann Fam Med[Internet]. 2015[cited 2018 May 3];13(6):523-28. Available from: http://www.annfammed.org/content/13/6/523.full

19. Backes DS, Pereira AD, Marchiori MT, Rupolo I, Backes MTS, Büscher A. Bonding professional-user: competence to act in the Family Health Strategy Team. Av Enferm [Internet]. 2015[cited 2018 Jul 10];33(2):222-9. Available from: http://dx.doi.org/10.15446/av.enferm.v33n2.50418

20. Silva CS, Souza KV, Alves VH, Cabrita BAC, Silva LR. Nurse's performance in prenatal consultation: limits and capabilities. Rev Pesqui: Cuid Fundam[Internet]. 2016[cited 2018 Jul 10];8(2):4087-98. Available from: http://www.seer.unirio.br/index.php/cuidadofundamental/article/ view/2009/pdf_1840 